\title{
OPSKRBA VODOM
}

Danijela BIRT

Sveučilište u Zadru

Odjel za etnologiju i kulturnu antropologiju

Ulica dr. F. Tuđmana 24 i, 23000 Zadar

Matija DRONJIĆ

Marmontova aleja 26

47000 Karlovac

\section{UVOD}

Stražujući teme iz materijalne kulture primorskih Bunjevaca na području Senjskoga bila i Krivoga Puta, tema opskrba vodom pokazala se kao nezaobilazna cjelina istraživanja koja svojim posebnostima može pridonijeti prikazu specifičnosti tradicijskoga načina života stanovnika ovoga kraja. Ova je tema na području Krivoga Puta istraživana u nekoliko navrata. Tijekom lipnja 2003. godine istraživanje je u dva navrata provedeno u sljedećim lokalitetima: Alan, Vrtlina, Rupa, Zamalić, Podbilo, Šimerići, Špalji, Cupići, Žuljevići, Francikovac. Sljedeće je započelo krajem svibnja 2004. u lokalitetima Krivi Put, Veljun, Šojatski Dolac, Mrzli Dol. Sustavnih istraživanja ove teme u hrvatskoj etnologiji nije bilo, stoga je bilo potrebno pripremiti upitnice. Početna upitnica (za polustrukturirani intervju) prilagođavala se i proširivala nakon rekognisciranja terena i preliminarnih razgovora s kazivačima na terenu.

Druga faza istraživanja provedena je u studenome 2007. godine ${ }^{1}$ te je bila znatno manjega opsega od prve faze, a tema istraživanja bili su tzv. grčki bunari. Pridjev „grčki“ pučka etimologija povezuje s predajnim graditeljima - Grcima koji su ih sagradili još za davnih vremena. Oni se često navode kao graditelji, ali ni sami kazivači nisu sigurni tko ih je gradio, iako su sigurni da postoje od davnina, tj. da su bili sagrađeni prije nego su Bunjevci doselili na spomenute prostore.

Izvora pitke vode nije bilo, pa su stanovnici po vodu odlazili u udaljena mjesta. Bez vode se nije moglo te su se ljudi morali dosjetiti kako bi i ovaj put prilagodili prirodne uvjete sebi. Većina kazivača ističe da se nisu kopali bunari, ali priče koje su čuli od starijih ljudi govore nam nešto drugo. Zbog problema u opskrbi pitkom vodom, stanovnici ovih krajeva nastojali su, također, na sve načine zadržavati kišnicu.

\section{PRIRODNI IZVORI VODE}

K azivači spominju nekoliko prirodnih izvora vode na koje je stanovništvo svakodnevno odlazilo po vodu. Na izvor Klenovnica u blizini Novog Vinodolskog i Crikvenice odlazili su stanovnici Rupe i Zamalića. Najvažniji izvor vode ovoga kraja nalazio se u Senjskoj Dragi, odnosno Majoriji (sl. 1). ${ }^{2}$

Tijekom 2007. godine provedena su istraživanja na području Krmpota i velebitskoga Podgorja gdje se istraživalo toponimiju te je zabilježen znatan broj legendi o grčkim bunarima. Stoga se pretpostavilo da bi ove teme trebalo istražiti i na području Krivoga Puta.

2 Marko Pavelić Mijatin, Žuljevići; Ivica Vukelić Pop, Rupa; Marko Tomljanović Cote, Šimerići; Tome Špalj Cucin, Špalji. 


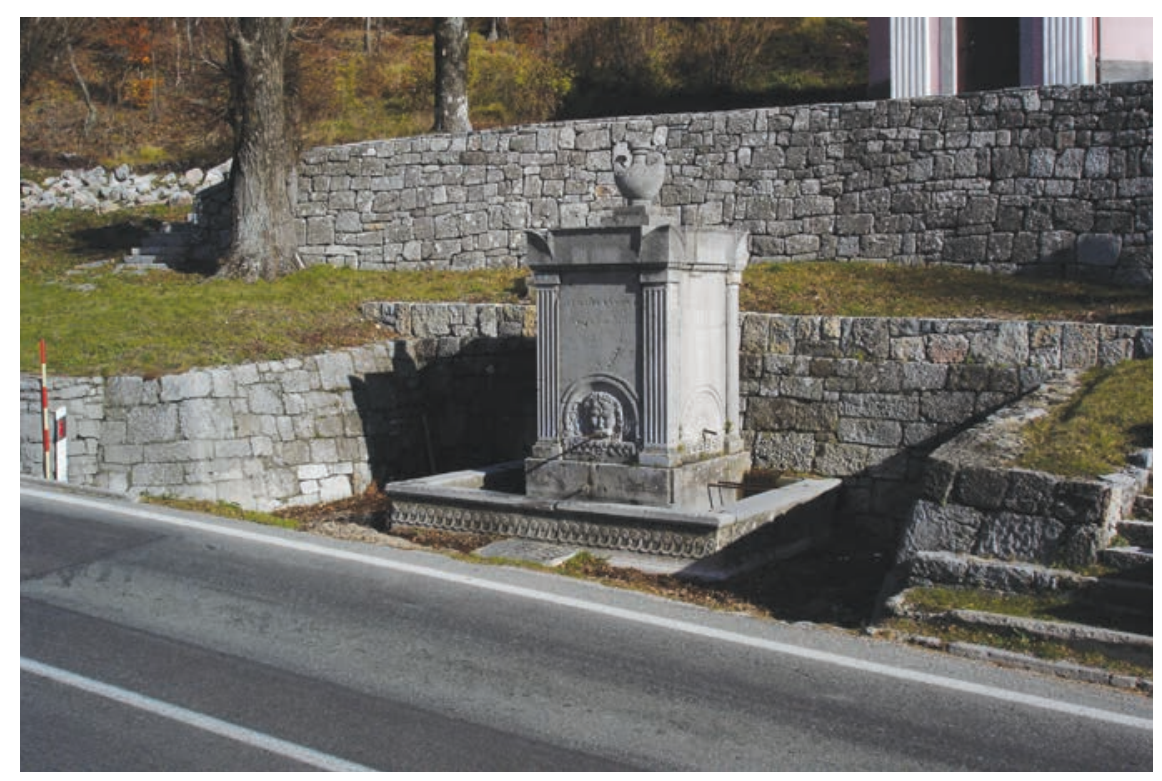

Slika 1: Izvor vode na Majoriji krupni plan; snimila Marijeta Rajković, studeni 2007.

Put dug šest kilometara često se prelazio i pješice. Voda se u takvim prilikama nosila u limenim posudama na glavi ili na leđima u manjim drvenim posudama, barilcima ili burilima. Mica Komadina Maričeva iz Alana prisjeća se uzrečice koja se često koristila kada bi netko duže vrijeme bio odsutan: $E$ ti, ko da si bio na Majoriji.

Iako je to bilo prilično naporno, najčešće su žene odlazile po vodu. To nije bilo pravilo, ali kako su muškarci često tijekom dana izbivali iz kuće, onda je na ženama bilo da se pobrinu i za vodu. Na izvore koji su se nalazili u neposrednoj blizini sela, svega nekoliko njih, odlazilo se po vodu i više puta tijekom dana ako je bila potreba. Ukoliko se po vodu odlazilo na izvore u Majoriju ili Klenovnicu, mjesta udaljena 20 i više kilometara od ovih sela, koristio se magarac pomoću kojega se na samaru moglo prenijeti i dva velika burila vode (oko 100 litara). Za obitelji koje nisu imale magarca ili u slučaju da se htjelo prenijeti više vode, koristila su se kola i konji. Tada se mogao prenijeti i puno veći teret, ograničen veličinom posude i udaljenošću puta. Iako su žene najčešće same odlazile po vodu, čak i na udaljene izvore u Majoriju i Klenovnicu, u prilikama kada se odlazilo po veću količinu vode zajedno je odlazilo nekoliko ukućana, najčešće oni koji su u tom trenutku slobodni; nitko nije posebno određivao tko će i kada ići. Po vodu se išlo kada bi je ponestalo ili kada se htjelo dodatno opskrbiti. U svakodnevnoj uporabi voda se neprestano koristila, tako je posuda s vodom stajala u kuhinji ili bajtici, domaćici na dohvat ruke.

Milan Tomljanović Perǐ̌a iz Zamalića također se prisjeća priča svoje bake, ona je pričala tu za zimska doba ona je na Malić tu je (bio, op. a) izvor mali izvor i onda je ona po dva sata čekala da se napuni, zatim je to natovarila na leda, to je bio mali izvor, tamo su i čobani odlazili.

Vodna ili Vodica, kako je neki nazivaju, manji je izvor smješten u neposrednoj blizini Zamalića i uvijek se koristio u nuždi ili kad se kosilo u poljima nedaleko sela tako da se nije morala nositi voda od kuće. Unatoč njegovu povoljnom položaju, izvor nije imao veću iskoristivost s obzirom da nije imao dovoljan kapacitet vode za okolna sela i često je presušivao. Ante Šojat iz Šojatskog Dolca napominje da se blago znalo goniti i na izvore, ako je bila suša ako vam je poznato gonilo se blago ovdje u Brinje u Liku, tamo je živa voda $i$ u Senjsku Dragu. ${ }^{3}$ Postojali su bunari i na Vratniku iz kojih su Krivopućani koristili vodu. Jedan je bunar građen 1844. godine, poznat kao Nikolin bunar, a drugi je nešto mlađi, iz 1899. godine (sl. 2 i 3).

\footnotetext{
Njegovo kazivanje potvrđuju Milan Krmpotić Zekonja i Luka Krmpotić Brnde iz Veljuna.
} 


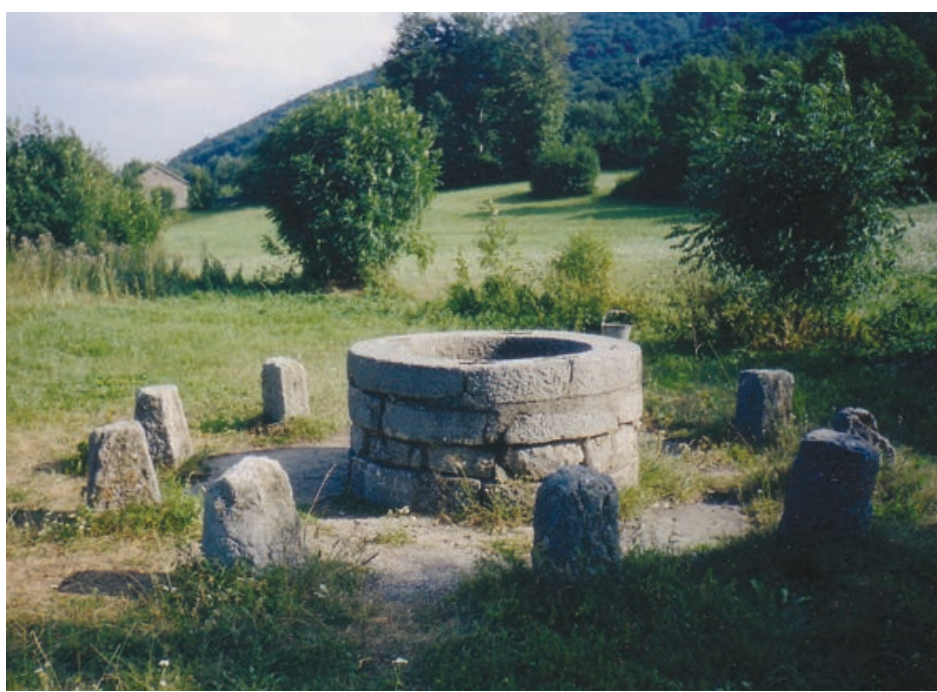

Slika 2: Nikolin bunar iz, 1844 godine na V ratniku; snimila Milana Cernelić, kolovoz 1999.

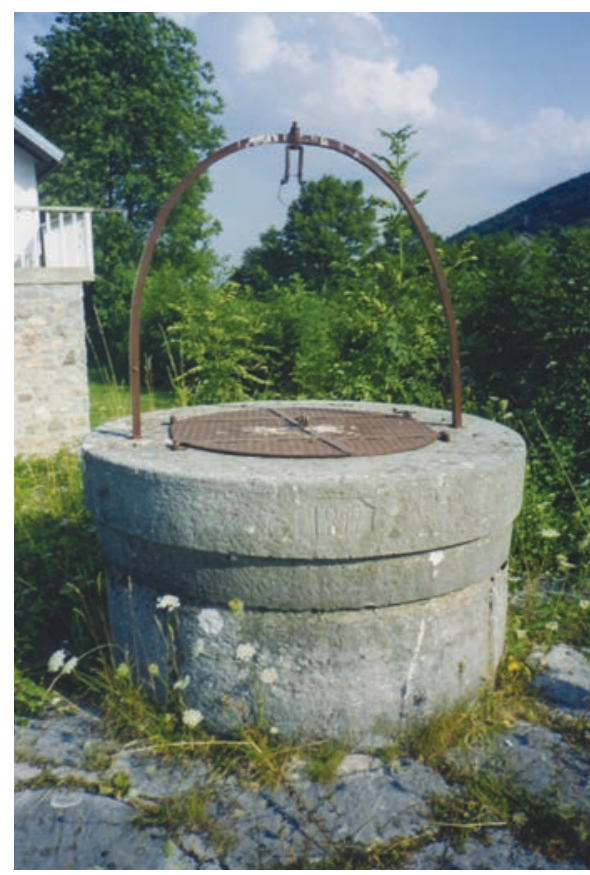

Slike 3: Bunar na V ratniku iz 1899. godine s koloturom; snimila Milana Cernelic, kolovor. 1999.

\section{3. ŠTERNE}

\section{1. OBITELJSKE ŠTERNE}

$\mathrm{N}$ ajrašireniji oblik rezervoara za zadržavanje kišnice jesu šterne, spremnici za vodu koje su tek u razdoblju nakon Drugoga svjetskog rata ušle u upotrebu u gotovo svakom kućanstvu (sl. 4, 4a). U prvoj polovici 20. stoljeća i ranije rijetko su kućanstva u selima općine Krivi Put posjedovala šternu, ponajviše iz financijskih razloga. Jedna od najstarijih je Popovska šterna koju je 1823. godine sagradio plovan Škiljan (sl. 5). ${ }^{4}$ U Rupi, prema kazivaču Ivanu Vukeliću Popu, šterna koju je 1782. godine sagradio netko od njegovih predaka najstarija je u selu i još je danas u funkciji. Također, jedna od starijih obiteljskih šterni, spomenuta od strane kazivača Tomislava Tomljanovića Talijana iz Zamalića, izrađena je 1912. godine za potrebe obitelji, a sagradio ju je njegov stric. Godine 1863. sagrađena je šterna obitelji Prpić u Francikovcu. Sagradio ju je Mile Prpić, pradjed kazivača, a kamen za te potrebe dopremili su iz Goljaka (kamenolom) kod Vratnika. Dakle, u početku gradnja šterni nije bila dostupna svima. U Podbilu je u razdoblju između dva rata bilo nekoliko obitelji koje su imale šterne: Baretina, Puljizova, Pave Toljina te Šuškalova. ${ }^{5}$ Svi kazivači slažu se s tim da je izrada šterne zahtijevala velika financijska sredstva. Stanovnici koji su odlazili na privremeni rad, ne samo unutar bivše države već i, kako navode neki kazivači, u Ameriku, na povratku bi nerijetko zarađeni novac koristili za gradnju šterne. Prilikom izbora bračnoga druga gledalo se i ocjenjivalo bogatstvo pojedine obitelji prema tome imaju li šternu ili ne. ${ }^{6}$ Prema kazivanju Ivice Vukelića Popa iz

4 Naziv Popovska šterna spominjali su svi kazivači, zapravo on je kao i većina naziva izveden iz toga tko je bio vlasnik šterne, kako je u ovom slučaju to bio seoski svećenik, pop, odatle potječe i naziv. Plovan je zapravo lokalni naziv za svećenika, plovanije je župni ured. Plovan Antun Škiljan jedan je od svećenika ove župe.

5 Marko Pavelić Mijatin, Žuljevići.

6 Više o načinu izbora bračnog druga vidi u drugom dijelu Monografije. 


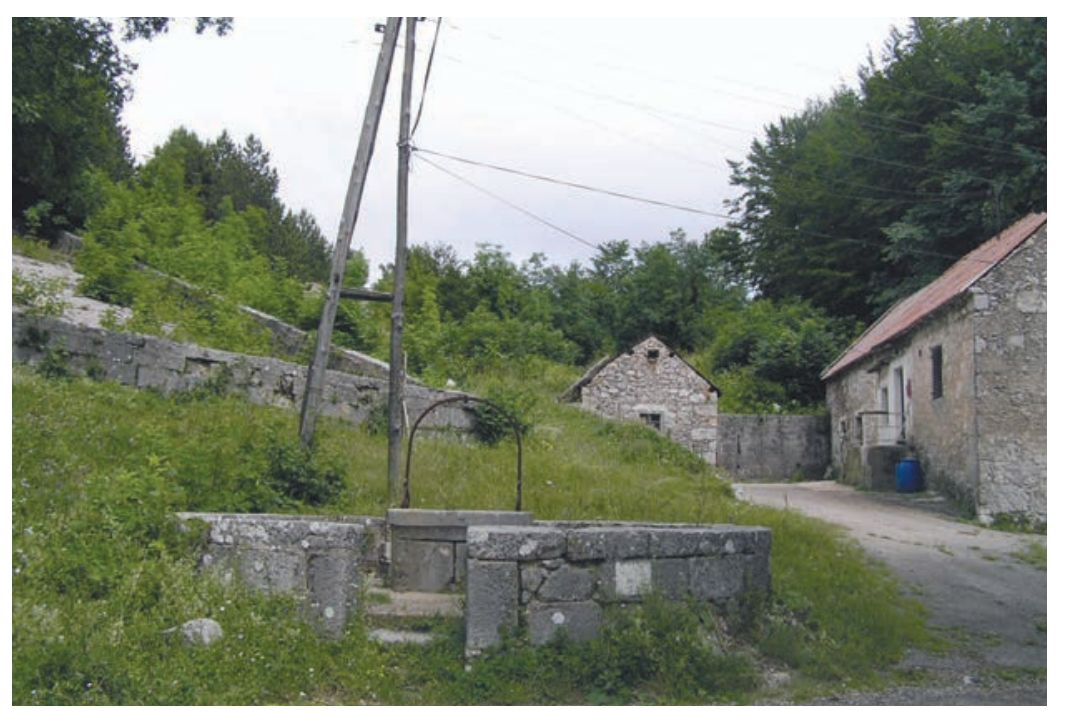

Slika 4: Kuía u Veljunu sobiteljskom i dř̌avnom šternom; snimila Marijeta Rajković, lipanj 2005.

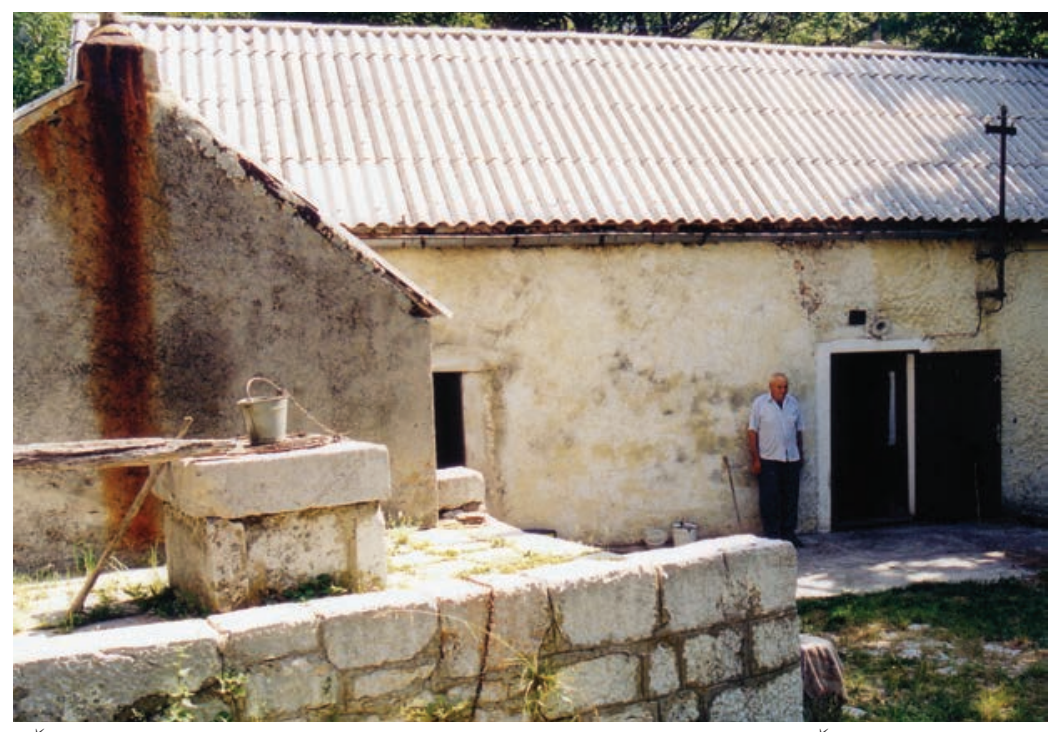

Slika 4a: Kuía u Špaljima sobiteljskom šternom, ispred kuće stoji vlasnik. Mile Špalj Kebin; snimio Augustin Peric, lipanj 2004. godine.

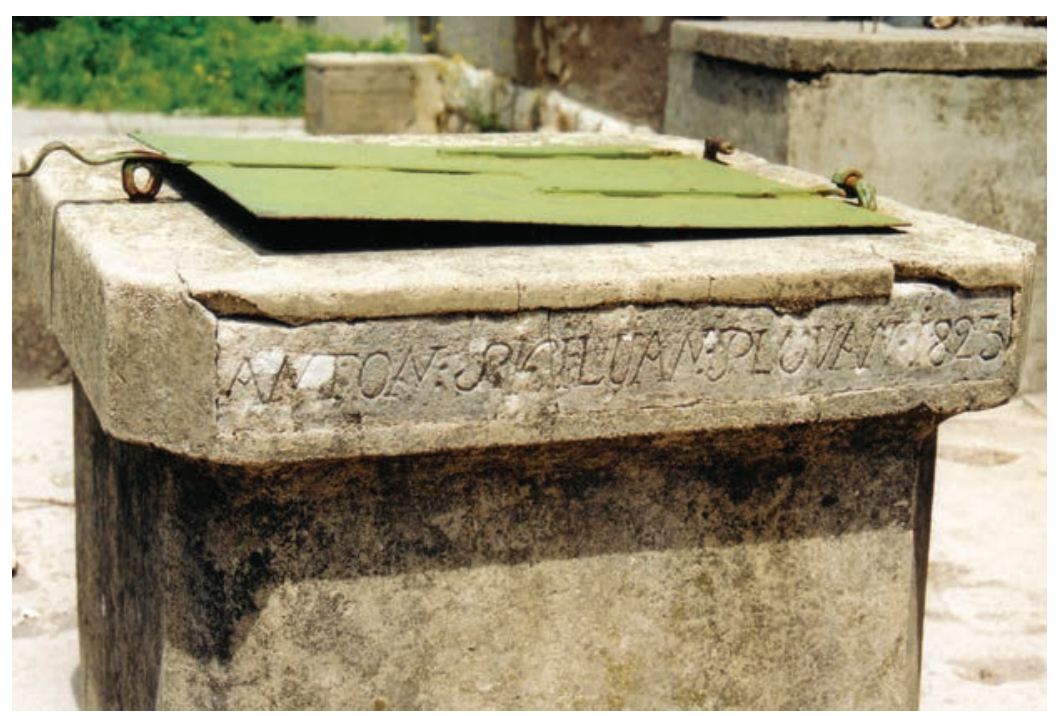

Slika 5: Detalj popovske šterne, Podbilo; snimio Auggustin Perić, lipanj 2003. 


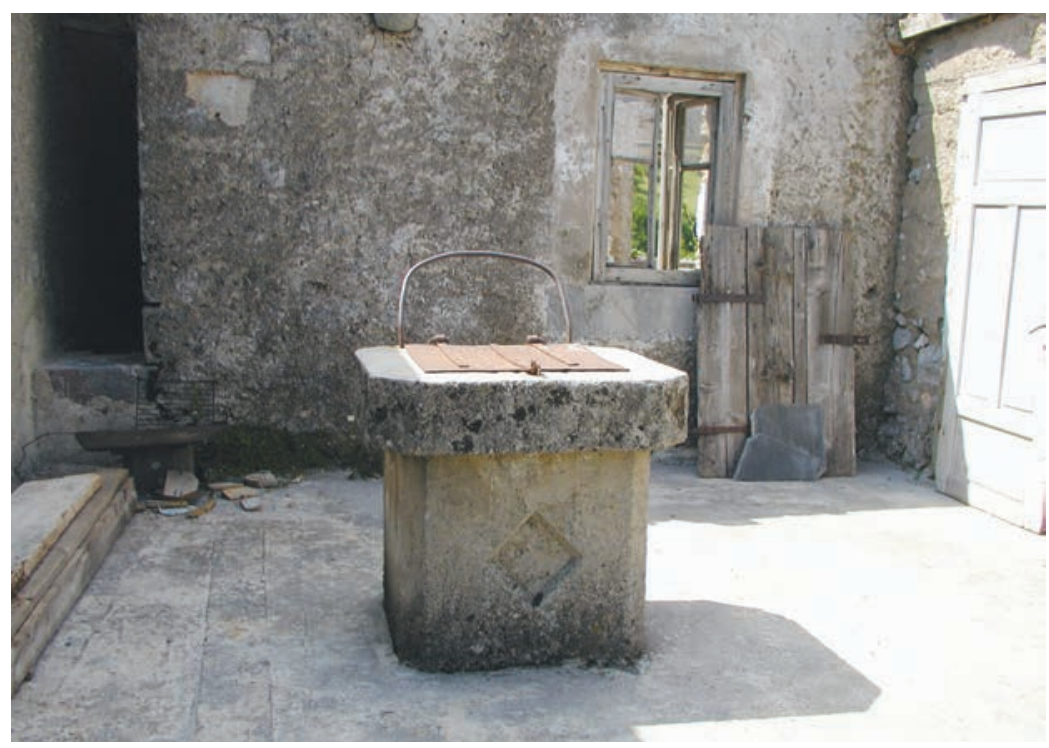

Slika 6: Šterna unutar stambenog prostora; snimila Jasmina Jurković, lipanj 2003.

Rupe, neke obitelji nisu imale svoje šterne pa premda bi im susjedi koji su imali šterne znali posuditi vode to za cijelu obitelj, koja je brojila i do desetak članova i stoku koju je imalo svako kućanstvo, nije bilo dovoljno (sl. 6). Slična kazivanja neki kazivači isključuju te navode da su ponekad žene i djevojke za kantu vode čitav dan morale u polju kopati ili žeti žito, o čemu svjedoči i uzrečica: Livadu je pokosila šterna!

Šterna obitelji Ivice Vukelića Popa iz Rupe sagrađena je 1829. godine. Služila je njegovoj obitelji, ali i okolnim kućama.

Danas je teško predočiti koliko je skupa bila gradnja šterni obzirom da su se vrijednosti promijenile, ali na upit o tome kazivači su se prisjetili. Primjerice, Marko Pavelić Mijatin iz Žuljevića prisjeća se da je on za svoju šternu svojedobno morao izdvojiti čak dvije krave, a taj iznos i danas je prilično impozantan. On je svoju prvu od tri šterne izradio 1924. godine.

Sam postupak izrade šterne zahtijevao je posebno umijeće i spretnost. U vrijeme kada su još Primorci ljeti selili na planinu sa stokom, a obzirom da su bili vješti u obradi kamena, kazivači napominju da su im nerijetko Primorci izrađivali šterne, a u zamjenu su stanovnici Krivoga Puta najčešće orali zemlju ili pomagali u košnji. Takav vid uzajamne pomoći nazivaju moba. Prvo što je bilo potrebno napraviti jest u zemlji iskopati rupu, zatim se dovozio kamen koji se obradio i njime se zidalo. Nije se koristilo nikakvo vezivno sredstvo, ali se iza kamena nabijala gnjila, glina koja nije propuštala vodu. Za dio šterne koji se ukopavao u zemlju nije zabilježen poseban naziv, dok se kameni dio iznad površine tla, koji je imao oblik četverokuta, nazivao grljak, kornjiš, ovo je grlo čitavo samo ovde uži a širji, od petuna se radilo a ima $i$ od 1 kamena (sl. 7). ${ }^{7}$ Taj dio, najčešće pola metra visok, promjera također pola metra, omogućavao je lakše izvlačenje vode (sl. 8). Poklopac koji se stavljao da pokrije otvor šterne najčešće se izrađivao u jednostavnijem obliku od drveta, a kasnije, ako su bili u mogućnosti, od željeza koje je postojaniji i otporniji materijal (sl. 9 i 9a). Voda iz šterne izvlačila se jednostavno pomoću kante i konopa ili uz pomoć koloture, posebne željezne konstrukcije koja se nadograđivala nad grljkom. Kolotura se pojavila nakon Drugoga svjetskog rata. Kada se voda izvlačila uz pomoć koloture kanta se stavljala na željezni lanac (sl. 3). Kanta ili kalača, što je učestaliji lokalni naziv, mogla je biti drvena, a kupovala se od majstora iz Kutereva kao i sve drvene posude, ili željezna, što se kupovalo najčešće na sajmovima ili trgovini u Senju.

Marko Pavelić, Mijatin, Žuljevići. 


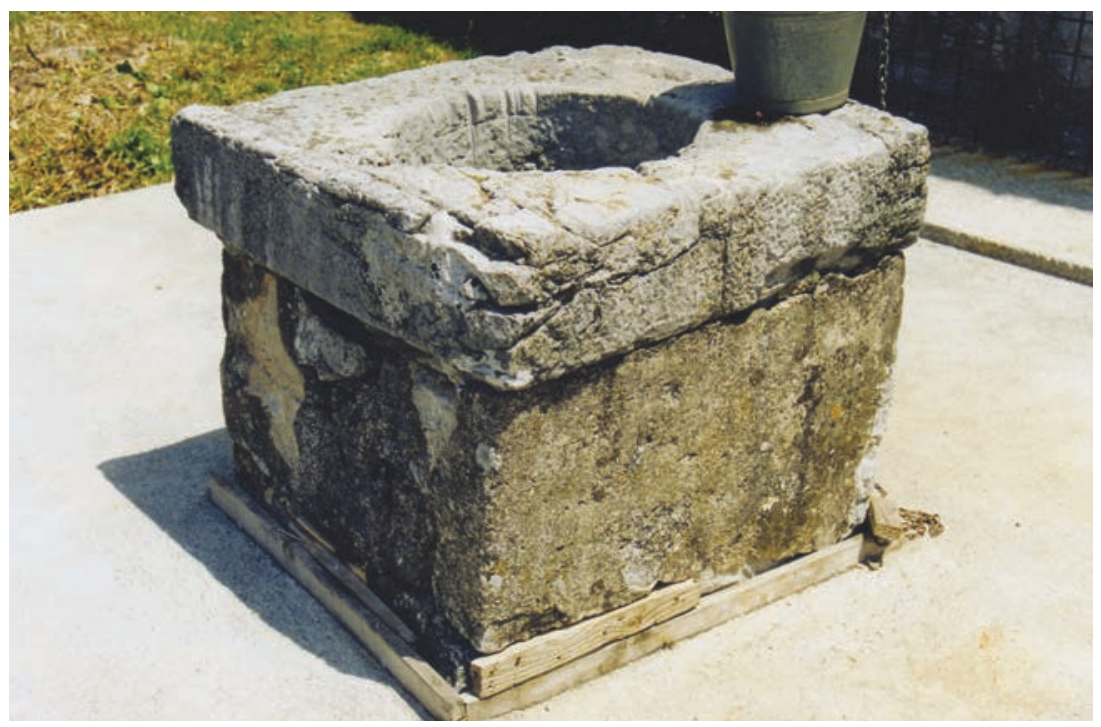

Slika 7: Grljak, Rupa; snimio Augustin Perić, lipanj 2003.

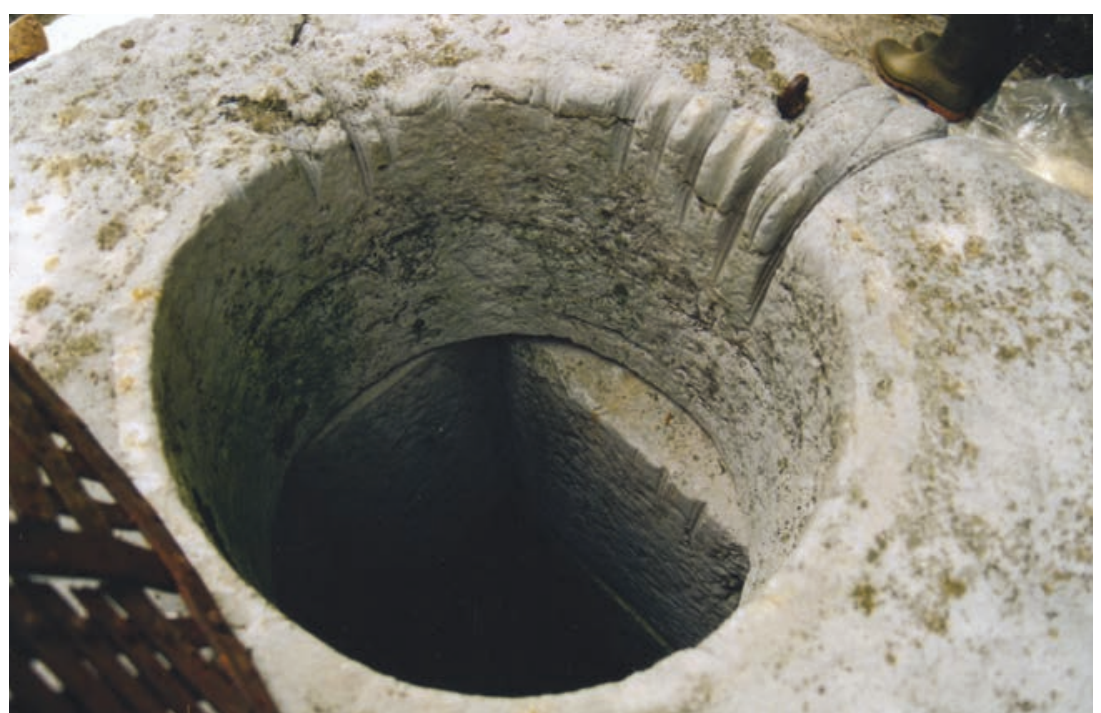

Slika 8: Otvor šterne u Cupicima; snimio Augustin Peric, lipanj 2003.

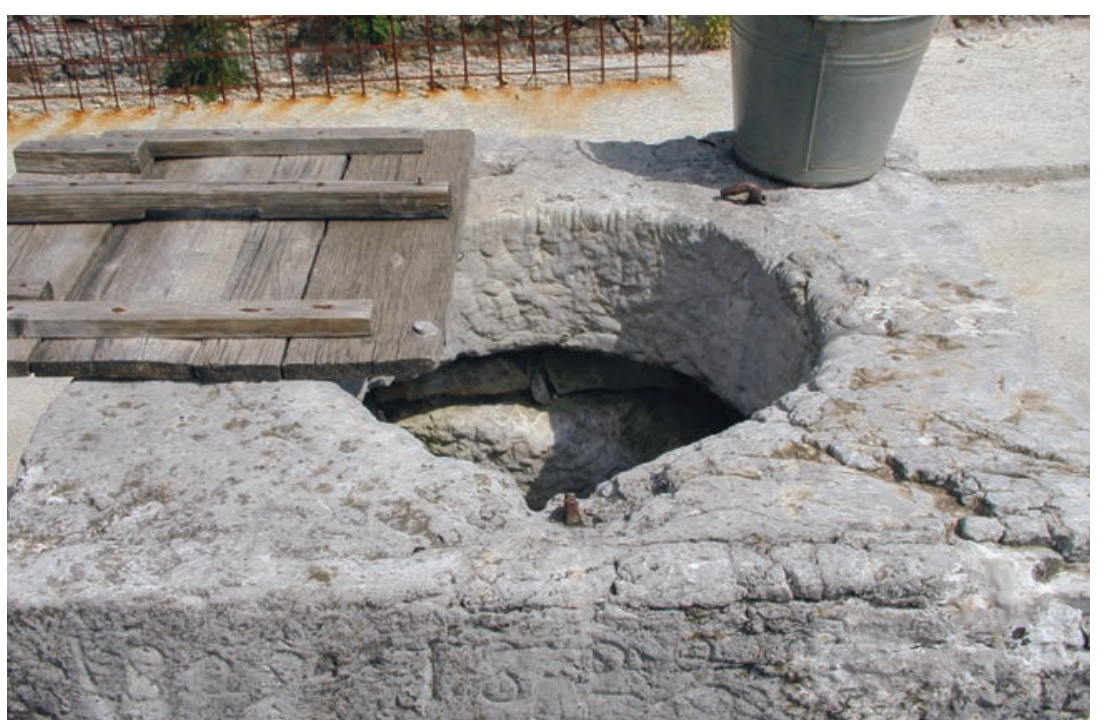

Slika 9: Drveni poklopac, Alan; snimila Jasmina Jurkovic, lipanj 2003. 
Od sedamdesetih godina sve do danas, stanovnici grade šterne od betona, ali se svi kazivači slažu u tome da je iz kamene šterne voda bila bolja. Danas neki imaju pumpe koje vodu dovode do slavina.

Veličina šterne ovisila je i o potrebama i mogućnostima pojedinoga domaćinstva. Kako je izrada šterne za pojedince bila i nemoguća, gradile su se što manje šterne, dovoljne za jedno kućanstvo, ali i tada se štedjelo.

Voda u šternama je kišnica koja se drvenim žljebovima, postavljenim na drvenim štapovima sojama, s krovišta dovodila do šterne (sl. 10). Drvene žljebove izrađivali su najviše od smrekovine.

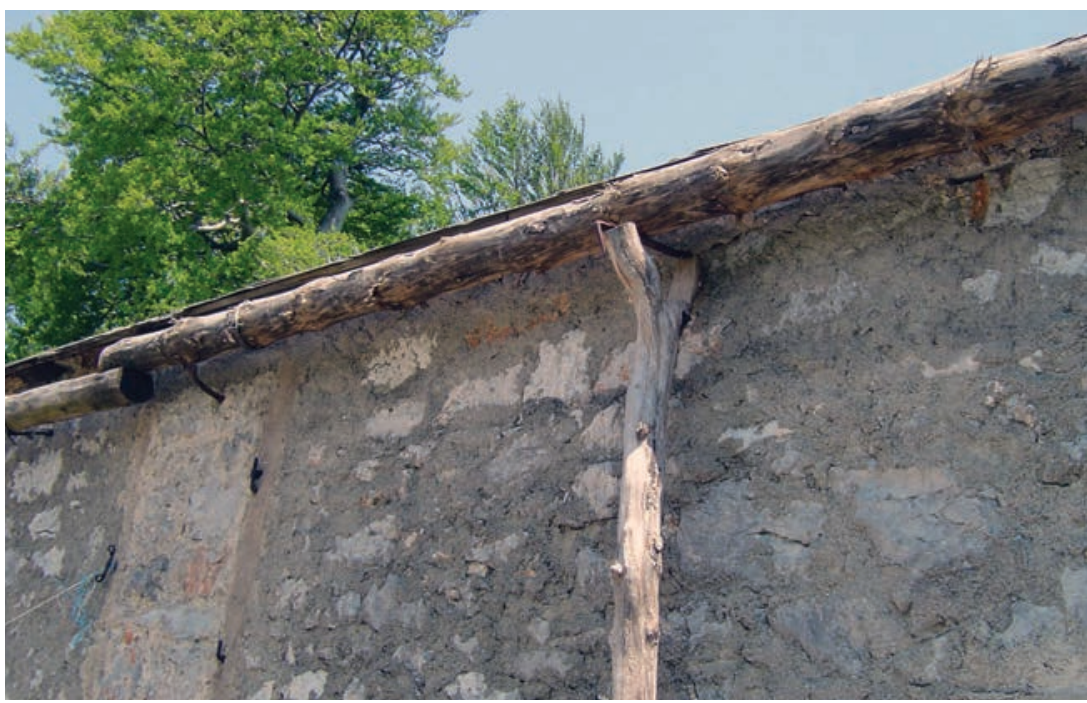

Slika 10: Soje u Veljunu na kući Milana Krmpotica Zekonje; snimila Danijela Birt, lipanj 2003.

Za sušne godine, kada nije bilo kišnice, voda se naročito štedjela. Nakon nekog vremena, vodu se pročišćavalo uz pomoć domaćega gašenog vapna. Na mjestu gdje je voda, koja se slijevala niz žljebove, ulazila u šternu stavljao se filter, tj. određena količina pijeska kroz koju je prolazila voda, tako se sva prljavština koja se slijevala s krova, lišće ili neke druge nečistoće, zaustavljala u pijesku.

\subsection{DRŽAVNE ŠTERNE}

Tržava je uvidjela teškoće stanovnika s vodom pa je nakon Drugoga svjetskog rata poticala organizirane radne akcije seljana u kojima su građene i šterne koje su sukladno s time dobivale naziv državne šterne (sl. 11). Gradile su se na padini, tako da se voda s velike betonske plohe slijevala u šternu. Na ovom ih je području bilo nekoliko, primjerice u Krivome Putu, Veljunu, Podbilu (Tomići) i Šojatskome Dolcu.

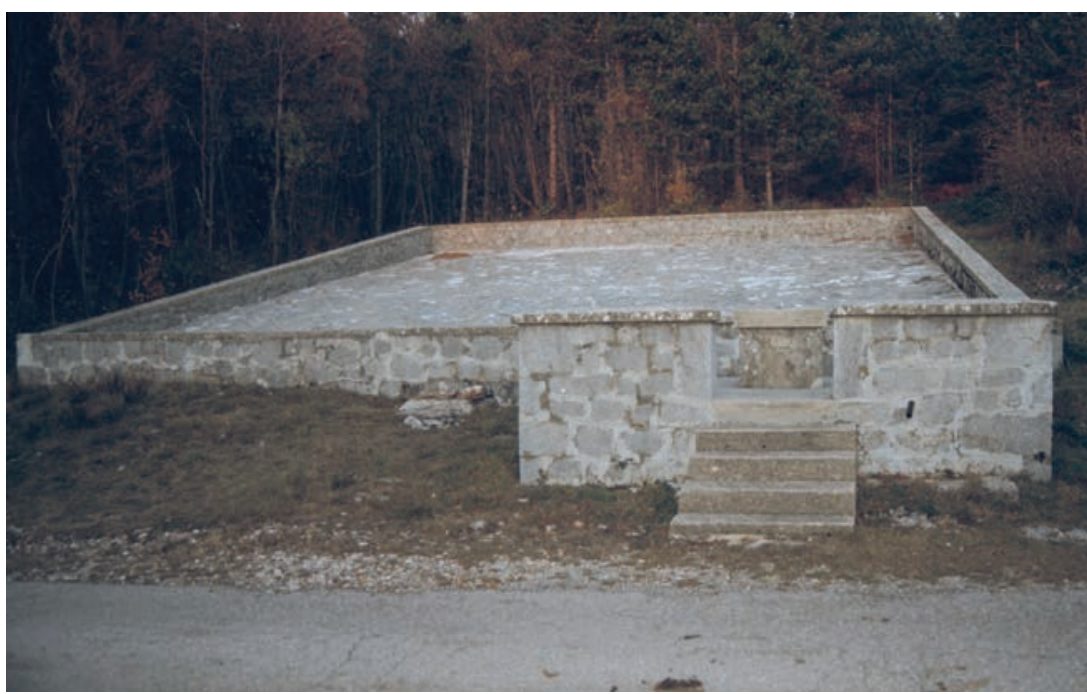

Slika 11. Dř̌auna šterna u Tomičima, Podbilo; snimio Augustin Perić, studeni 2007. 
Iako stanovništvo koje je ostalo u selima posjeduje u svojim kućanstvima šterne, a postoje i državne šterne, problem opskrbe vode i dalje je prisutan. Ponajviše zato što ovisi o vremenskim prilikama s obzirom da je voda u šternama kišnica. Prilikom istraživanja utvrđeno je kako danas gotovo svako domaćinstvo u Krivome Putu posjeduje šternu (sl. 12). Zbog velike potrebe za vodom, posebice ljeti kada kiše ima najmanje, za one koji ljeti borave u svojim kućanstvima u Krivome Putu ili zbog onih koji tijekom cijele godine moraju imati više vode primjerice zbog uzgoja veće količine stoke, stanovnici vodu naručuju od Vatrogasnog društva Senj koji je dopremaju u cisternama. Tomu smo bili svjedoci u Škopcima kada je voda dopremljena obitelji Krmpotić Bokulići koja se bavi uzgojem krava.

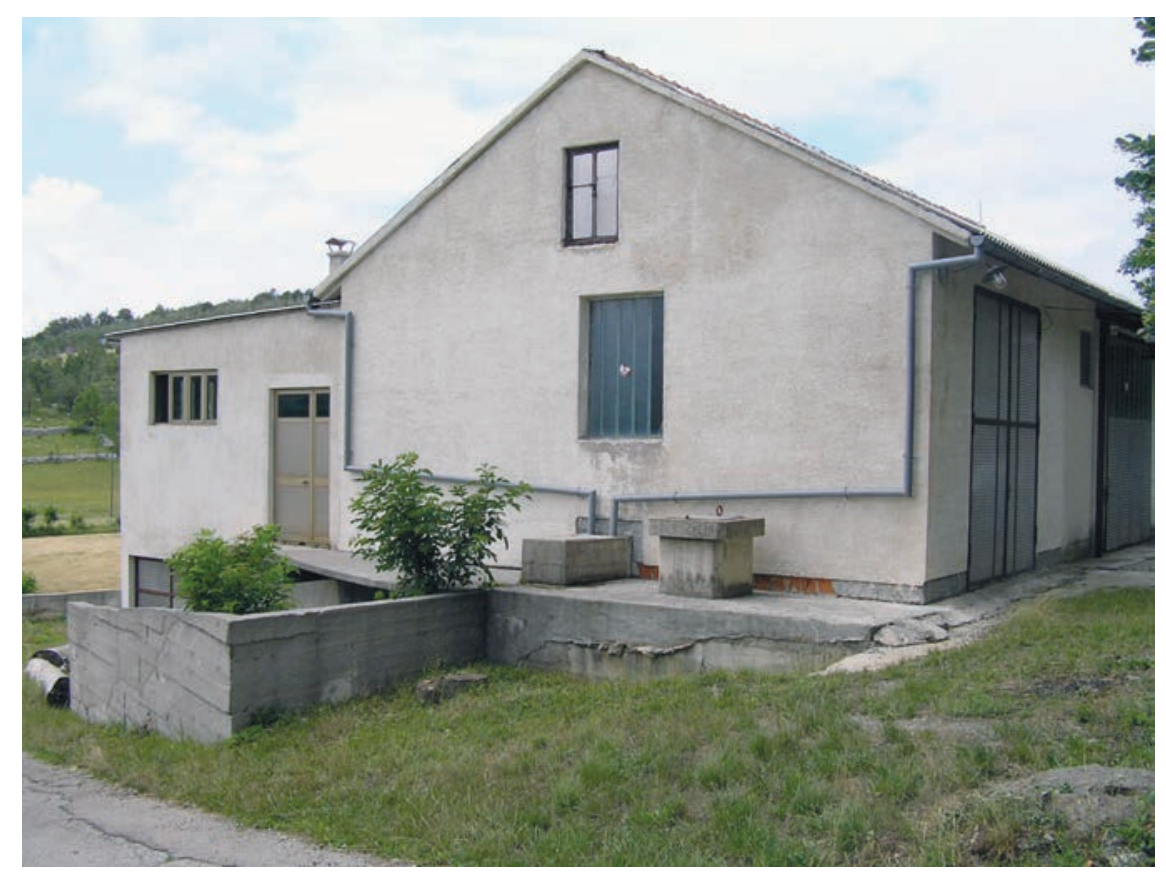

Slika 12: Suvremena kuća u Veljunu sobiteljska šternom; snimila Marijeta Rajković, lipanj 2005.

\section{LOKVE}

$\mathrm{L}$ jeti kada je stoka odlazila izvan sela na ispašu, napajala se na lokvama. Pri izradi lokve ljudi su se koristili već postojećim prirodnim udubinama, koje su se nalazile uz puteve kojima se stoka vodila na ispašu. Takve udubine očistili su i proširili, a na dno se nabijala glina, ako je već nije bilo, ili bi se dno oblagalo kamenom. Lokve smještene unutar sela ili u blizini livada ili u šumi bile su postojane, pod uvjetom da nije bila sušna godina. Ponekad su se žene znale poslužiti lokvama i za pranje rublja, s time da su uzimale samo vodu i prale bi izvan lokve, a preko ljeta dječaci su se u njima znali i kupati. Svake godine obavezno su se čistile, zapravo samo se uredilo dno, no danas više nisu prepoznatljiva mjesta na kojima su se nalazile, od kada nema stoke nestale su lokve. ${ }^{8}$ Zapravo je to bio vrlo uzajaman odnos: svojim svakodnevnim dolaskom na lokvu stoka ju je i održavala jer bi se ulaskom u vodu zemlja na dnu lokve zbijala i time je ona bila nepropusnija i u njoj se duže zadržavala voda. Unatoč njihovoj jednostavnosti i tome što za njihovu izradu nije bilo potrebno izdvojiti novac, lokve su zahtijevale neke oblike zajedničkog rada kada bi ih kopali i čistili.

No, nešto je drugačije na području Veljuna. Tamo je gotovo svaka kuća imala svoju lokvu, no to su bile manje lokve koje su koristili ljudi za svoje potrebe. Na njima se napajala i stoka, ali pored takve lokve

\footnotetext{
Zlata Tomljanović Pešina, Krivi Put.
} 
obavezno se nalazio i kopanj u kojeg su ljudi iz lokve lijevali vodu za stoku. U velikim lokvama stoka je ulazila u vodu i tako pila.

Svako selo imalo je i nazive za svoje lokve. U Šojatskom Dolcu zabilježeno je i nekoliko naziva lokvi kao što su: Ujičina, Gredina i Kujičina (lokva u Podbilu) lokva. Kazivač Milan Krmpotić Zekonja iz Veljuna spomenuo je još nekoliko lokvi u blizini svog sela: Puljizova (lokva u Podbilu), Kaunova, Psehova, Brezova, Brndina (lokva njegova susjeda) i njegova lokva, Zekonjina. Podrijetlo naziva pojedinih lokvi proizlazi iz nadimaka njihovih vlasnika ili osoba čije su se kuće nalazile u blizini lokve. U Francikovcu postoji legenda da je Marija Terezija kada je putovala ovim krajevima na jednoj lokvi popila vode i proglasila tu vodu ljekovitom, pa ta lokva danas nosi ime Likarevac. ${ }^{9}$

Koliko se voda poštivala prikazuju nam riječi Pere Vukelića Mrce iz Vukelića: onda je moj did sidija tu, onda dode neki Stipe, tu mu je bila kuća sad je srušena, i cigar je u ruci ima i kad je did vidija cigar i viče: Stipe, pazi da cigar ne padne u vodu. I Ivka Tomljanović Maričina iz Alana prisjeća se svog djeda: E did naš, nije se smjelo pred njima davat drugima vodu, a baba je skrivečki i robu prala kad je suša bila.

\section{DRVENE POSUDE ZA VODU}

P ostojalo je nekoliko vrsta drvenih posuda u kojima se prenosila voda. O načinu izrade i materijalima koji su se koristili kazivači nisu previše znali obzirom da ih nitko na području Krivoga Puta nije izrađivao, nego su sve kupovali od Kutarevaca. ${ }^{10}$ Ali prema njihovim pretpostavkama najviše su koristili hrastovinu, trešnju, šljivu, orah i javor. Sve posude izrađene su od drvenih daščica, širine oko tri centimetra, učvršćenih s dva ili tri metalna obruča. Zabilježeno je nekoliko različitih vrsta: bačva, burilo/burlo i barilac, žbanjica. Razlike između pojedinih posuda su u volumenu i obliku, te načinu izrade.

Bačva je drvena posuda duguljastog oblika, s donje je strane zatvorena, a na vrhu cijelim dijelom otvorena i tu se ulijeva voda. U tako otvorenoj bačvi voda se teško prevozila, pa su se ljudi dosjetili staviti na površinu vode nekoliko grana ili lišće koje bi zaustavile prelijevanje. ${ }^{11}$ Volumen bačve, prema kazivanjima pojedinih kazivača, može se odrediti u razmjerima od 100 do 200 litara. ${ }^{12}$

Burilo/burlo, volumena od 25 do 50 litara, također je duguljasta oblika. ${ }^{13}$ Kada se kosilo, radilo u polju ili u šumi, kosci su sa sobom obavezno nosili i vodu. Ako bi išli od kuće na nekoliko dana vodu su nosili u burilima, a ako su odlazili nedaleko od kuće nosili bi u žbanjicama. ${ }^{14}$ Osim toga, burila su se najviše koristila prilikom odlaska na izvor kada se prevozila voda za domaćinstvo. Prilikom prijevoza burila su se konopima vezala na samar. Milan Krmpotić Zekonja iz Veljuna prisjeća se novca koji su morali izdvojiti za burilo veličine 30 litara - bilo je to 20 dinara. Naravno, cijena je ovisila o veličini posude, ali i o vrsti drveta od kojeg je izrađena.

Žbanjice su volumena od 5 do 10 ili 15 litara. Prilično su lagane i puno praktičnije od burila (sl. 13). Drugačijeg su oblika od burila i bačve, dno je u obliku elipse, nešto šire su na dnu, a prema vrhu se sužavaju. ${ }^{15}$ Žbanjice imaju i dršku kroz koju se provlačio konopac, pomoću nje se žbanjica vezivala na samar ili se nosila na kosistu. ${ }^{16}$ Barilac je posuda slična burilu, ali volumenom puno manja (sl. 14). Prema kazivanjima svih kazivača ima jednu rupu kroz koju se voda ulijevala i izlijevala, za razliku od ostalih posuda koje imaju dvije rupe.

\footnotetext{
Marija Terezija (1740.-1780.), austrijska carica.

Kutarevci je lokalni naziv za Kuterevčane, stanovnike Kutereva.

Nada Prpić Terezina, Krivi Put.

Milan Krmpotić Zekonja, Veljun; Zlata Tomljanović Pešina, Krivi Put.

3 Tomo Špalj Cucin, Senj; Zlata Tomljanović Pešina, Krivi Put; Milan Krmpotić Zekonja, Veljun.

4 Marija Rončević Garina, Alan; Milan Tomljanović Periša, Zamalić; Zlata Tomljanović Pešina, Krivi Put.

5 Nikola Prpić Nikolčin, Francikovac; Milan Krmpotić Zekonja, Veljun.

16 Milan Tomljanović Periša, Zamalić; Milan Krmpotić Zekonja, Veljun.
} 


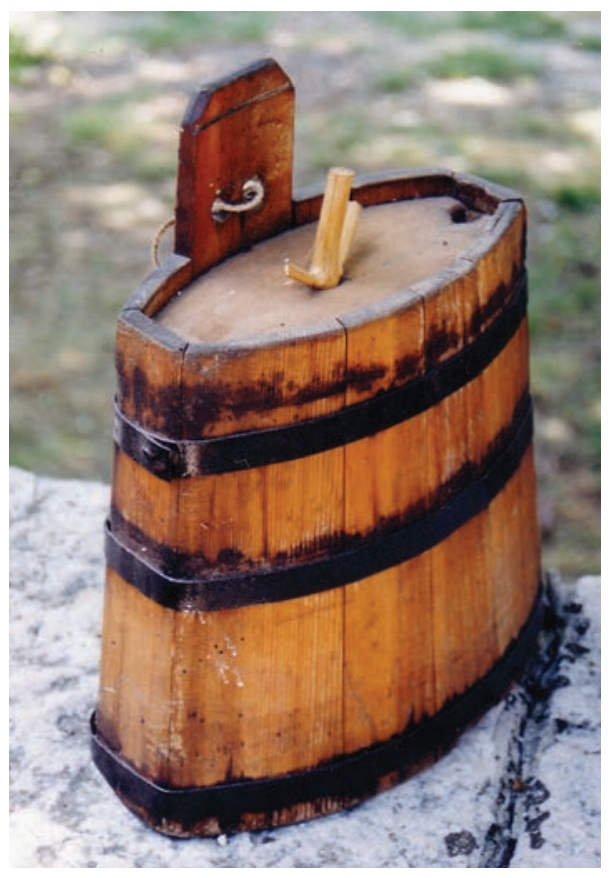

Slika 13: Žbanjica; vlasnik Milan

Tomljanović Ivić, Cupiči; snimio Augustin Peric, lipanj 2003.

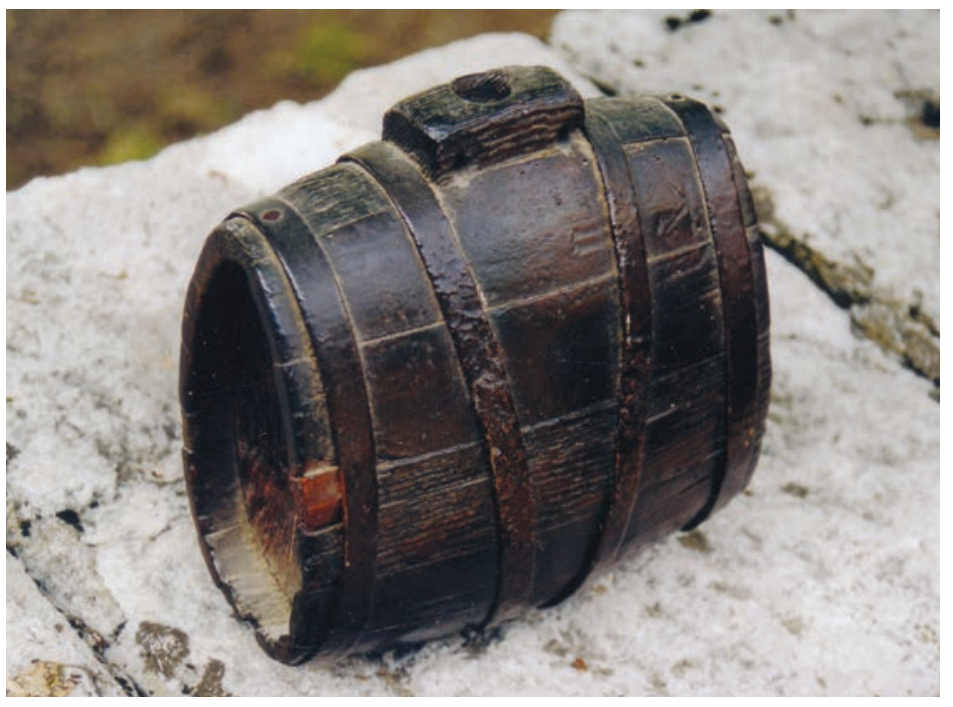

Slika 14: Barilac, vlasnik Milan Tomljanović Ivić, Cupiči; snimio Augustin Peric, lipanj 2003.

Sve posude imaju škulju, rupu kroz koju se ulijevala voda. Drvene posude izrađivali su Kutarevci koji su svoje proizvode donosili prodati na sajmove, primjerice, u Otočac i Brinje. Ta-

kođer, često su znali prolaziti selima s natovarenim kolima i tako prodavati ne samo posude za vodu već $\mathrm{i}$ sve ostalo što su izrađivali u svojim radionicama. ${ }^{17}$

Prema kazivanjima iz Podbila, Cupića, Vrtline i Alana i led se prevozio u Senj. Kada bi zimi u jamama u šumi napadao snijeg pokrili bi ga lišćem te bi se tako dosta dugo zadržao, pa su ga ljudi ljeti u obliku leda vozili u Senj za sladoled i za hlađenje pića i mesa, mesarima i u ribarnice. Vozili bi led noću na magarcu u vrećama. Led se nije koristio za vlastite potrebe već se samo prodavao. ${ }^{18}$

\section{GRČKI BUNARI}

$\mathrm{N}$ ajjednostavniji način da se opiše grčki bunar jest da ga se usporedi s obzidanom lokvom koja služi za skupljanje kišnice. Različitih su dimenzija, uglavnom kružnog oblika, te su obzidani kamenim blokovima različite kvalitete obrade. I danas zadržavaju vodu iako su zapušteni zbog nekoliko razloga, prvenstveno zbog depopulacije područja tijekom 20. stoljeća. Također, nakon Drugoga svjetskog rata seljani sve više grade obiteljske šterne, ali i država intervenira te se podižu velike šterne javnog karaktera. Uvelike umanjen broj stanovnika rezultirao je razmjerno umanjenim brojem domaćih životinja, te su šterne uglavnom bile dostatan izvor pitke vode dok bunari zarastaju u vegetaciju i bivaju uništavani. Prema riječima Marka Pavelića Mijatine, djeca su u igri u bunar pobacala ono što je bija zid okolo, te navodi kako ih seljani nakon toga nisu obnavljali, što je vidljivo prema stanju u kojem se danas nalaze. Bitno je spomenuti da, za razliku od sterne, bunar nema gornji kamen (voltu), iako se isti kazivač prisjeća da su ljudi ponekad, da uštede novac, radili šterne bez volte koje su vizualno različite od grčkih bunara.

Većina kazivača navela je kako grčki bunari nikad ne presušuju, no jedan od najstarijih kazivača, Marko Pavelić Mijatin, sjeća se kako su oba presušila za vrijeme tridesetih godina 20. stoljeća. Isti se kazivač

\footnotetext{
17 Vidi prilog o tradicijskoj trgovini i sajmovima u ovoj monografiji. 18 Isto.
} 
prisjetio njihova izgleda u vremenu kada su korišteni, govoreći da je više od metar do dva zid bio gore. Također, navodi kako su bili zajednički, te su se svi Krivopućani njima koristili i zajednički ih održavali.

Na području Podbila nalaze se dva bunara. Jednog mještani nazivaju Dražica $(s l .15,15 a){ }^{19}$ i nalazi se uz nekadašnji put koji je vodio preko Alijinog bila. Danas se naziru samo konture puta, ali nekada je bio dovoljno širok da su po njemu mogla ići kola. Naime, u ljetnim su mjesecima Krivopućani vodili domaće životinje na ispašu uglavnom prema Alijinu bilu, pa i s njegove druge strane. ${ }^{20}$ Tamo su se također nalazile livade koje su kosili is kojih su spomenutim putem sijeno na kolima dovozili u naselja. ${ }^{21}$

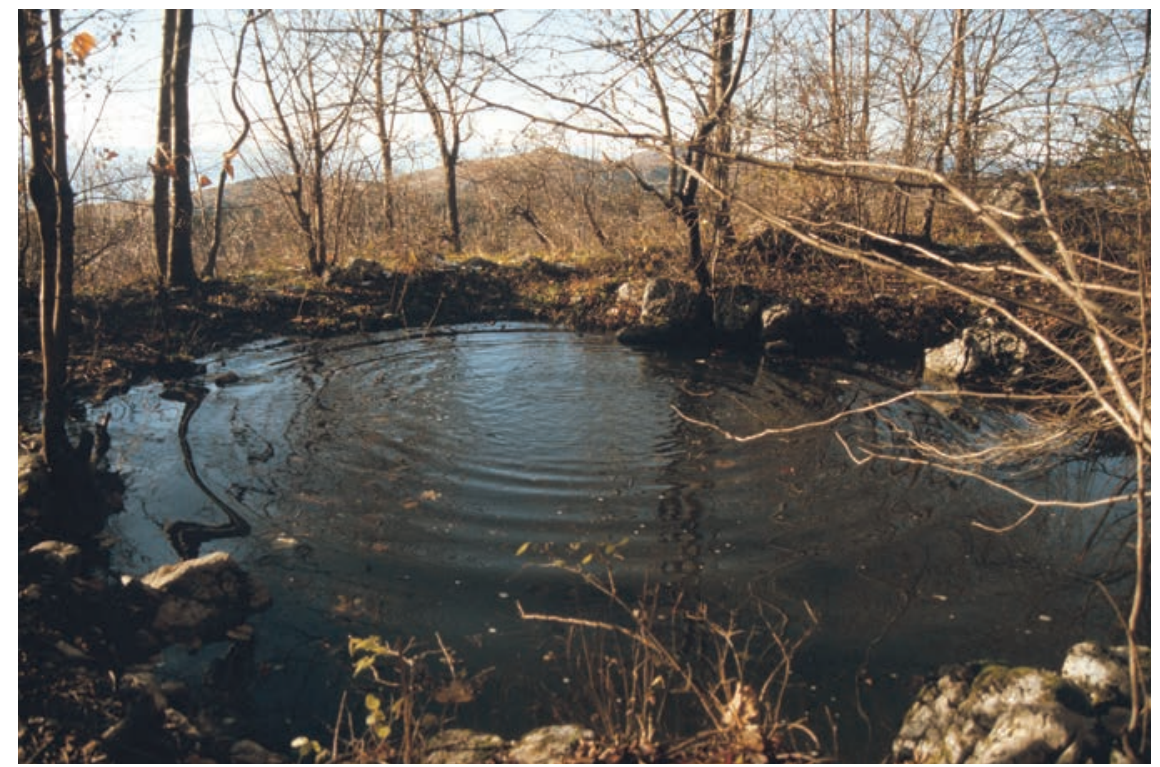

Slika 15: Grčki bunar Dražica u Podbilu; snimio Matija Dronjić, studeni 2007.

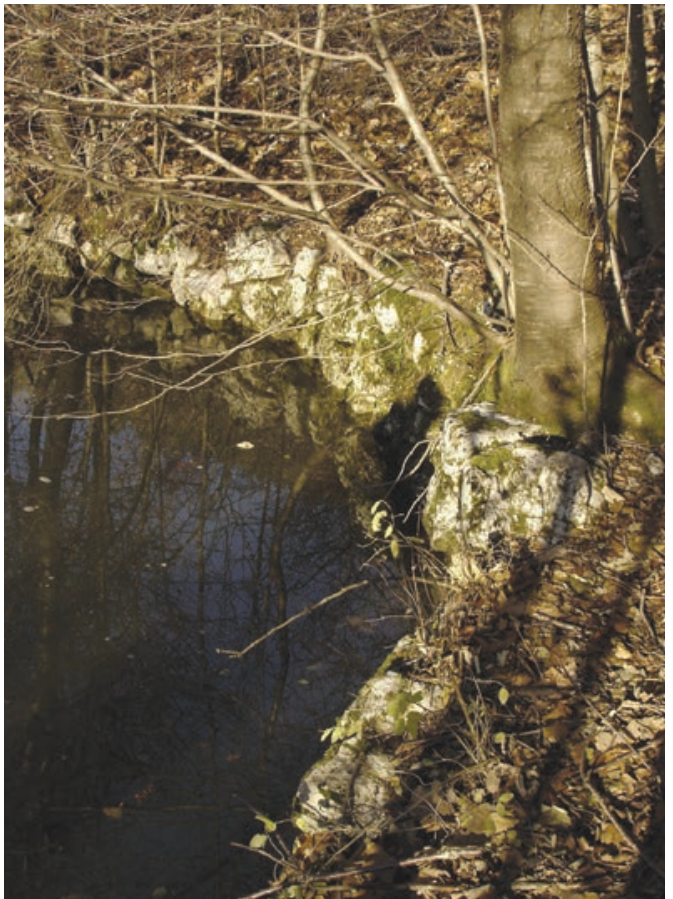

Slika 15a: Dražica - ostatak kamenog obæida u Podbilu.

19 Ivan Tomljanović Čona, Marin Tomljanović, Marko Pavelić Mijatin.

20 Više o organizaciji ispaše vidi kod M. Rajković u ovoj monografiji.

${ }^{21}$ Detaljnije o sjenokoši vidi kod M. Rajković, a o transportu kod D. Birt u ovoj monografiji. 


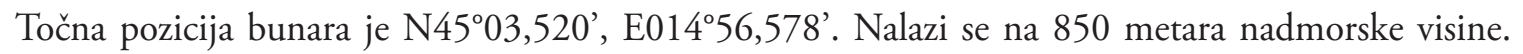
Bunar je gotovo nemoguće pronaći u krajobrazu bez vodiča, ${ }^{22}$ budući da je zbog nekorištenja zapušten i obrastao šumom. Kružnog je oblika i još uvijek su vidljivi ostaci kamena obzida, načinjena od grubo obrađenih kamenih blokova.

Među lokalnim stanovništvom postoje legende o bunarima i njihovim graditeljima, pa se tako, primjerice, Tomo Špalj Cucin iz Špalja prisjeća što mu je govorila baka: tu nema nigdje žive vode na našim planinama, ovde kod Klaričevca ima jedan bunar sedam sa sedam, vako okrugel $i$ to kažu da su to delali stari Grci, dal je to istina il ne, al u najvećoj suši tu je bilo vode. Sličnih priča prisjećaju se i Marko Pavelić Mijatina iz Žuljevića, Marija Tomljanović Tolina iz Krivoga Puta te Nikola Prpić Nikolčin iz Francikovca koji također spominju grčki bunar, ali na Šturi.

Te priče mogu se dovesti u vezu s drugim bunarom koji je smješten u Pekinom Dolcu i Krivopućani ga nazivaju Štura (sl. 16). ${ }^{23}$ Nalazi se na N4502,904', E01455,677', na puno nižoj nadmorskoj visini od Dražice $(637 \mathrm{~m})$. Iako se nalazi u dolini, nemoguće ga je primijetiti jer je obrastao šumom. Bunar je nekada bio kružnoga oblika, ali moguće je utvrditi da je u nekom trenutku proširen, tako da je segment kruga otvoren, te se iz njega voda proširila tvoreći lokvu nepravilna oblika na čijem se rubu ocrtava barem $2 / 3$ originalna oblika ograđena zidom od neobrađena ili grubo obrađena kamenja različitih veličina.

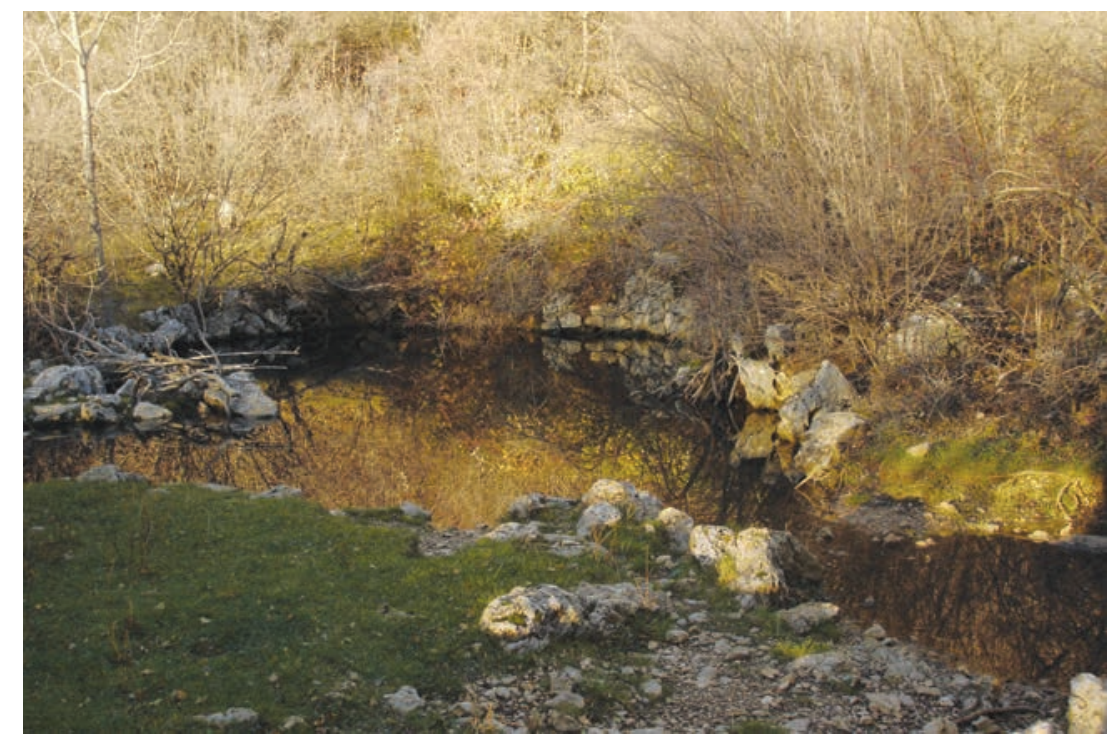

Slika 16: Bunar Štura u Pekinom Dolcu (Podbilo); snimio Matija Dronjić studeni 2007.

Zanimljivo je spomenuti jednu crticu iz pučke etimologije koja se donekle može povezati s pitanjem o identitetu graditelja bunara. Iako ih stanovništvo na širem području naziva grčkim bunarima, neki ih povezuju s Turcima. O njihovu prisustvu na ovom području svjedoče brojne usmene predaje, ${ }^{24}$ ali i toponimi, stoga je potrebno spomenuti priču o Aliji po kome je prozvano Alijino bilo. Prema kazivanju Marka Pavelića Mijatine, koji govori da je po pričama koje je čuo od starijih Alija (je) bio Turčin koji je (...) na hiljade ovaca ima. I krepivale su mu od zime. Ne bi nakosija sijena i...

Dakle, možemo pretpostaviti da je spomenuti Alija bio bogat čovjek ukoliko se uzme u obzir količina ovaca. Moguće je pretpostaviti da se radilo o istaknutom članu zajednice jer spomenuti kazivač govori da

22 Zahvaljujem se Marinu Tomljanoviću koji me je odveo do oba bunara, r. 1980, Tomići.

23 Ivan Tomljanović Čona, Marin Tomljanović, Marko Pavelić Mijatin.

24 Primjerice, Marko Pavelić Mijatin govori kako je zaselak Plemići “tursko” selo. 
je prema predaji Alija imao pastire u službi. Navodi stihove pastirske pjesme koja objašnjava zbog čega se bilo nazvalo po njemu:

\section{Alija, Alija nogu slomija \\ usrid bila di složena bila. ${ }^{25}$}

Ivica Vukelić Pop iz Rupe i Pero Vukelić Mrco iz Vukelića i danas znaju za mjesto na obližnjem brdu, koje lokalno stanovništvo naziva Alijinim brdom jer je navodno Alija (turski vojskovođa) upravo na mjestu gdje se nalazi jedan od bunara u ovom području slomio nogu.

Ni Marko Pavelić Mijatin, jedan od najstarijih mještana, ne može precizirati tko su bili graditelji bunara, ali neizravno navodi mogućnost da su ih i Turci gradili. On spominje da su ti bunari bili Alijini u nekom razdoblju, ali treba biti oprezan $s$ pretpostavkom da su im graditelji bili Turci jer takvih analogija gotovo da i nema na širem prostoru u kojem žive primorski Bunjevci. ${ }^{26} \mathrm{Za}$ većinu stanovnišstva oni su grčki bunari, tj. građeni od Grka koji su ovdje boravili u pradavna vremena.

Iako grčki bunari nisu dovoljno istraženi, bilo bi netočno reći kako se nitko nije bavio problematikom njihova nastanka. Pokojni prof. Ante Glavičić posvetio im je dio jednog svog članka objavljena u Senjskom zborniku, u kojem navodi neke primjere grčkih bunara iz Senja i okolice te govori kako je vrijeme njihova nastanka nepoznato. Zaključuje da ih ljudi dovode u vezu sa starim Grcima, iako napominje da stari Grci nisu nikada živjeli u ovim krajevima, ali je sigurno da su u njih zalazili. Ipak iznosi mišljenje kako se tehnika gradnje može dovesti u vezu sa starim Ilirima, a moguće i s još starijim Mediterancima. (usp. Glavičić 1967/8: 39-40)

\section{ZAKLJUČAK}

Z bog specifičnoga prirodnog okruženja na području Krivoga Puta opskrba vodom predstavljala je elementarnu životnu potrebu stanovništva. Takva situacija oblikovala je tradicijski način života i elemente materijalne kulture koje je ovo istraživanje prvenstveno trebalo prikazati.

Prilikom prve faze istraživanja, koja je provedena u dva navrata 2003. i 2004. godine, prikupljeni su podaci o prirodnim izvorima vode kojima se koristilo stanovništvo, o gradnji i načinu korištenja obiteljskih, crkvenih i državnih šterni. Nadalje, prikupljeni su podaci o lokvama na kojima je stanovništvo napajalo stoku, te su navedene i opisane drvene posude koje su služile za transport i čuvanje pitke vode. Godine 2007. provedena je druga faza istraživanja u kojoj su locirana dva tzv. grčka bunara i neke legende vezane uz njihove navodne graditelje.

Na temelju analize sakupljene građe može se zaključiti da su Krivopućani imali poseban odnos prema vodi. Ona je bila dragocjena što potvrđuje činjenica da se katkad prelazio put duži od 20 kilometara kako bi se došlo do nje. U odnosu prema vodi sadržan je i bitan socijalni moment jer je evidentno da je svima bilo u interesu da se održavaju lokve na kojima se mogla napajati stoka i sl. Također, kroz ovu se temu produbilo shvaćanje trgovačkih odnosa Krivopućana s okolnim zajednicama te elementi njihove duhovne kulture zadržani u raznim legendama i poslovicama koje samo dodatno naglašavaju koliko je voda bila važna stanovništvu ovoga područja.

\section{LITERATURA}

GLAVIČIĆ, Ante (1967/68), Arheološki nalazi iz Senja i okolice (II), Senjski zbornik, 3:5-45. Senj.

25 Kazivač Marko Pavelić Mijatin nije znao objasniti značenje ovoga nejasnog stiha.

26 Podatke sakupio Matija Dronjić tijekom istraživanja u velebitskom Podgorju u studenom 2007. 
